University of Nebraska - Lincoln

DigitalCommons@University of Nebraska - Lincoln

Faculty Publications from the Harold W. Manter Laboratory of Parasitology

10-1977

\title{
Poecilancistrium caryophyllum and Other Trypanorhynch Cestode Plerocercoids from the Musculature of Cynoscion nebulosus and Other Sciaenid Fishes in the Gulf of Mexico
}

Robin M. Overstreet

Gulf Coast Research Laboratory, robin.overstreet@usm.edu

Follow this and additional works at: https://digitalcommons.unl.edu/parasitologyfacpubs

Part of the Parasitology Commons

Overstreet, Robin M., "Poecilancistrium caryophyllum and Other Trypanorhynch Cestode Plerocercoids from the Musculature of Cynoscion nebulosus and Other Sciaenid Fishes in the Gulf of Mexico" (1977). Faculty Publications from the Harold W. Manter Laboratory of Parasitology. 295.

https://digitalcommons.unl.edu/parasitologyfacpubs/295

This Article is brought to you for free and open access by the Parasitology, Harold W. Manter Laboratory of at DigitalCommons@University of Nebraska - Lincoln. It has been accepted for inclusion in Faculty Publications from the Harold W. Manter Laboratory of Parasitology by an authorized administrator of DigitalCommons@University of Nebraska - Lincoln. 


\title{
POECILANCISTRIUM CARYOPHYLLUM AND OTHER TRYPANORHYNCH CESTODE PLEROCERCOIDS FROM THE MUSCULATURE OF CYNOSCION NEBULOSUS AND OTHER SCIAENID FISHES IN THE GULF OF MEXICO*
}

\author{
Robin M. Overstreet \\ Gulf Coast Research Laboratory, Ocean Springs, Mississippi 39564
}

\begin{abstract}
Examination of over 3,000 fish, all sciaenids, has shown that plerocercoids of Poecilancistrium caryophyllum infect Cynoscion nebulosus, Bairdiella chrysura, Sciaenops ocellata, C. arenarius, Micropogonias undulatus, and Pogonias cromis in Mississippi Sound. In addition to P. caryophyllum, a pseudophyllidean-like trypanorhynch also infected C. nebulosus and $M$. undulatus. Pseudogrillotia pleistacantha selectively infected large $P$. cromis, Pterobothrium heteracanthum infected $M$. undulatus, and Pterobothrium lintoni infected Menticirrhus americanus. Prevalence and intensity of infections of P. caryophyllum in C. nebulosus from Mississippi, roughly $40 \%$ of the fish each possessing an average of about two worms, compare with infections observed in fish from Texas and Louisiana. However, values for fish from Apalachee Bay, but not Tampa Bay, Florida, are about twice as high. Extensive seasonal sampling in Mississippi Sound indicates fluctuations but no clear-cut seasonal trends other than a possible relationship between infections and salinity. As C. nebulosus increases in length, the prevalence of infections, but not the intensity, increases. This finding suggests an immune response to challenge infections. No fish less than $140 \mathrm{~mm} \mathrm{SL}$ and relatively few less than $250 \mathrm{~mm}$ SL revealed infections, suggesting either the unavailability of the intermediate host to young fish or the ultimate death of most young infected individuals. Based on condition coefficients and liver-weight analysis, no apparent detrimental effect on infected, moderately-heavy adult fish occurred. Infections primarily involve the middle of a fillet or the region adjacent to the vertebral column below the dorsal fins and cause an esthetically displeasing product and consequently depress economically the trout fishery. Relatively more male than female fish harbored worms, but the significance of that finding is questioned.
\end{abstract}

The esthetic appearance of trypanorhynchs in the musculature of sciaenid fishes discourages many people from eating estuarine fishes in the northern Gulf of Mexico. Most prevalent in Mississippi is Poecilancistrium caryophyllum (Diesing 1850) in the economically important spotted seatrout, Cynoscion nebulosus (Cuvier). Easy to observe as a chalky opaque object against the greyish translucent background of a fillet, the typical $6 \mathrm{~cm}$ long plerocercoid twists or folds within a 3 to $4 \mathrm{~cm}$ long space. Infected seatrout have the common name "wormy trout." Based on an absence of human infections with this or related species and on unsuccessful attempts to

Received for publication 28 January 1977.

* This study was conducted in cooperation with different agencies: the U.S. Department of Commerce, NOAA, National Marine Fisheries Service, under PL 88-309, Project No. 2-262-R and Office of Sea Grant, under Grant No. 04-6158-44060, and the Public Health Service, Food and Drug Administration, Contract No. 223-762141. The U.S. Government is authorized to produce and distribute reprints for governmental purposes notwithstanding any copyright notation that may appear hereon. experimentally infect kittens (Boertje, 1976) or rats and mice (unpublished), infected fish should not be considered a public health problem.

This study provides identifications and brief comments for fairly common trypanorhynchs infecting the flesh of sciaenids in and near Mississippi Sound. Using data restricted to $P$. caryophyllum in the spotted seatrout, it additionally reports seasonal incidence and intensity of infections and relates infections to salinity and temperature of water, host length, and host sex; compares findings with additional data from Texas, Louisiana, and Florida; determines common infection sites within the host; and investigates the effect of plerocercoids on hosts.

\section{MATERIALS AND METHODS}

During every season between summer 1972 and fall 1975, an attempt was made to examine at least 30 spotted seatrout less than $250 \mathrm{~mm}$ standard length (SL) and a similar number of greater length. With the exception of a few samples from Texas, Louisiana, and Florida, all fish came from Mississippi Sound; except for several caught by trawl or hook and line, all came from reliable commercial fishermen or suppliers and remained on 


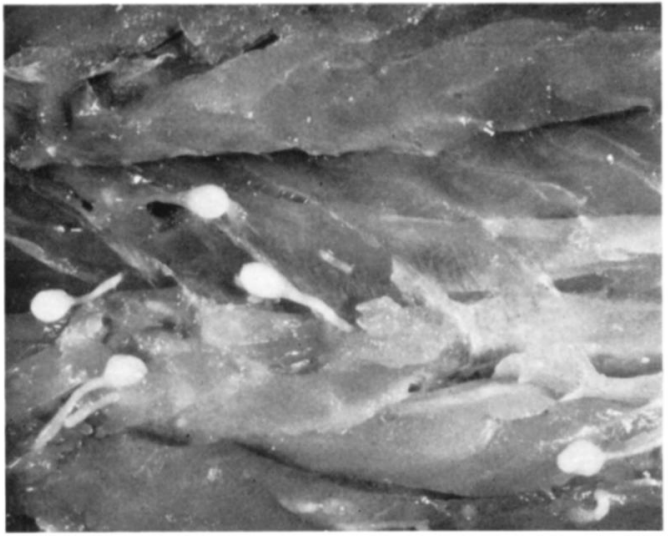

Figure 1. Five exposed blastocysts of Poecilancistrium caryophyllum in filleted spotted seatrout. Scolex of plerocercoid occurs within bulb.

ice until examined. Additional sciaenid species were examined periodically. Following weighing and measuring of each fish, both with and without gonads and liver (for computation of condition coefficients), it was filleted and all plerocercoids removed after their locations were noted. Cestodes were measured and weighed, but since their weight remained insignificant compared to that of the host, those data are omitted. The membrane surrounding the scolex was mechanically disrupted to protrude tentacles for positive identifications of all worms during the first 2 years and of most thereafter.

Salinity and temperature of the water monitored at the Gulf Coast Research Laboratory pier twice a week provided a good relative representation of those parameters for Mississippi Sound to use for relating with infections.

\section{RESULTS}

\section{Species encountered}

In addition to infecting Cynoscion nebulosus, the most common host (Fig. 1), Poecilancistrium caryophyllum also occurred in five of nine other sciaenid fishes (Table I). I have examined numerous fishes other than sciaenids over the past few years without encountering this most prevalent sciaenid trypanorhynch. A few specimens, considered developing plerocercoids of $P$. caryophyllum, exhibited a typical blastocyst but an incompletely developed scolex. These worms measured up to $23 \mathrm{~mm}$ long, but perhaps others reaching $80 \mathrm{~mm}$ are the same. Histologic similarity occurred between the developing plerocercoid and the fully-developed $P$. caryophyllum larva when based on corresponding tissues from the "scolex region" and the blastocyst's elongated "caudal" extension.

Four other histozoic trypanorhynchs occurred at least in two individual fish. One from spotted seatrout and Atlantic croaker superficially appeared like a pseudophyllidean because its active, pointed, unarmed, anterior end lacked either bothria or bothridia and could invaginate. Its musculature, however, looked typical of a trypanorhynch blastocyst, but differed from that in $P$. caryophyllum. The species, capable of reaching over $60 \mathrm{~mm}$ in length, infected fish during the first two seasons of 1972 and earlier. Neither larvae fed to baby mallard ducks and white mice nor those surgi-

Table I. Sciaenids in Mississippi Sound examined between summer 1972 and fall 1975 for Poecilancistrium caryophyllum in their musculature.

\begin{tabular}{|c|c|c|c|c|c|c|c|}
\hline Fish & $\begin{array}{c}\text { No. } \\
\text { examined }\end{array}$ & $\begin{array}{c}\text { No. } \\
\text { infected }\end{array}$ & $\begin{array}{c}\text { Range } \\
\text { of fish } \\
\text { in } \mathrm{cm} \mathrm{SL}\end{array}$ & $\begin{array}{c}\text { Range of } \\
\text { infected } \\
\text { fish } \\
\text { in } \mathrm{cm} \mathrm{SL}\end{array}$ & $\begin{array}{l}\text { Prevalence } \\
\text { in infected } \\
\text { length- } \\
\text { group }\end{array}$ & $\begin{array}{c}\text { Maximal } \\
\text { no. of } \\
\text { worms }\end{array}$ & $\begin{array}{c}\text { Intensity } \\
\text { per } \\
\text { infected } \\
\text { fish }\end{array}$ \\
\hline \multicolumn{8}{|l|}{ Cynoscion nebulosus (Cuvier), } \\
\hline Bairdiella chrysura (Lacépède), & & & & & & & \\
\hline silver perch & 141 & 5 & $3-17$ & $12-15$ & 15.6 & 2 & 1.2 \\
\hline Sciaenops ocellata (Linnaeus), red drum & 19 & 2 & $4-51$ & $25-51$ & 15.4 & $\overline{2}$ & 2.0 \\
\hline $\begin{array}{l}\text { Cynoscion arenarius Ginsburg, sand seatrout } \\
\text { Micropogonias undulatus (Linnaeus), }\end{array}$ & 263 & 10 & $5-33$ & $14-33$ & 9.6 & 1 & 1.0 \\
\hline Atlantic croaker & 174 & 13 & $6-34$ & 9-33 & 8.2 & 7 & 1.5 \\
\hline $\begin{array}{l}\text { Pogonias cromis (Linnaeus), black drum } \\
\text { Menticirrhus americanus (Linnaeus), }\end{array}$ & 8 & 1 & $13-91$ & $91 *$ & $100 *$ & 1 & 1.0 \\
\hline southern kingfish & 725 & $\mathbf{0}$ & $6-36$ & - & - & - & - \\
\hline Leiostomus xanthurus Lacépède, spot & 64 & $\mathbf{0}$ & $7-23$ & - & - & - & - \\
\hline $\begin{array}{l}\text { Menticirrhus littoralis (Holbrook), } \\
\text { gulf kingfish }\end{array}$ & 8 & $\mathbf{0}$ & $4-7$ & - & - & - & - \\
\hline Larimus fasciatus Holbrook, banded drum & 7 & $\mathbf{0}$ & $6-10$ & - & - & - & - \\
\hline
\end{tabular}

* Based on single infected fish; additional infections discussed in text. 
cally implanted into chick intestines could be recovered after several days.

Pseudogrillotia pleistacantha Dollfus 1969, referred to by fishermen as "the spaghetti worm," specifically infected large individuals of the black drum. No fish $68 \mathrm{~cm}$ or shorter possessed the worm. Conversely, almost all longer drum, including many observed but not listed herein, harbored it, with individuals locating near the caudal portion in large fish. Degenerate worms commonly occurred, as well as "pockets" which worms apparently previously occupied. A fish typically hosted 5 to 15 specimens averaging about $14 \mathrm{~cm}$ long.

Specimens of Pterobothrium lintoni (MacCallum 1916) up to $5 \mathrm{~cm}$ long infected southern kingfish off Empire, Louisiana, but not in Mississippi. Plerocercoids of the related $P$. heteracanthum Diesing 1850 ranging between 12 and $64 \mathrm{~mm}$ long when considering the blastocyst extension occurred in both the musculature and body cavity of a few Atlantic croaker. Other trypanorhynchs infecting sciaenids from Mississippi were only encountered once and will not be treated here.

\section{Poecilancistrium caryophyllum in spotted seatrout}

Prevalence and intensity of infection: Prevalence of $P$. caryophyllum in Mississippi Sound was $30.0 \%$ of the infected length-group with 1.7 worms per infected seatrout (Table I). Seasonal incidence values for fish longer

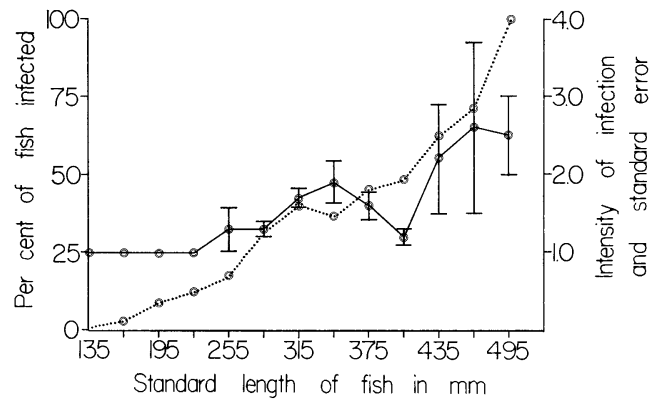

Figure 2. The prevalence (dotted line) and intensity (solid line plus and minus one standard error) of spotted seatrout from Mississippi Sound infected with Poecilancistrium caryophyllum as related to the host's standard length in $10 \mathrm{~mm}$ increments.

than $249 \mathrm{~mm}$ fluctuated (Table II) with yearly values ranging between 26 and $49 \%$. During each year, peaks tended to occur during or near summer months, but because seasonal values differed considerably among years, the suggested trend is partially masked. Observed infections did not occur in seatrout shorter than $140 \mathrm{~mm}$ and rarely involved those shorter than $250 \mathrm{~mm}$ (Table II and Fig. 2). Not until spring 1973 did any young fish reveal infections.

Intensity and length of worms portrayed no obvious seasonal trends (Table III). Yearly intensity levels for fish longer than $249 \mathrm{~mm}$ ranged between 1.5 and 1.8 worms per fish.

TABLE II. Seasonal incidence of different-sized spotted seatrout from Mississippi Sound infected with Poecilancistrium caryophyllum.

\begin{tabular}{|c|c|c|c|c|c|c|}
\hline \multirow[b]{2}{*}{ Season } & \multicolumn{2}{|c|}{ Fish $<140 \mathrm{~mm} \mathrm{SL}$} & \multicolumn{2}{|c|}{ Fish 140 to $249 \mathrm{~mm} \mathrm{SL}$} & \multicolumn{2}{|c|}{ Fish $>249 \mathrm{~mm} \mathrm{SL}$} \\
\hline & $\begin{array}{l}\text { Number } \\
\text { examined }\end{array}$ & $\begin{array}{l}\text { Percent } \\
\text { infected }\end{array}$ & $\begin{array}{l}\text { Number } \\
\text { examined }\end{array}$ & $\begin{array}{l}\text { Percent } \\
\text { infected }\end{array}$ & $\begin{array}{l}\text { Number } \\
\text { examined }\end{array}$ & $\begin{array}{l}\text { Percent } \\
\text { infected }\end{array}$ \\
\hline Summer '72 & 14 & 0 & 1 & 0.0 & 22 & 63.6 \\
\hline Fall 72 & 41 & 0 & 8 & 0.0 & 29 & 37.9 \\
\hline Winter' 73 & 58 & 0 & 5 & 0.0 & 13 & 61.5 \\
\hline Spring '73 & 83 & 0 & 44 & 0.0 & 43 & 16.3 \\
\hline Summer ' 73 ' & 0 & - & 22 & 9.1 & 31 & 29.0 \\
\hline Fall '73 & 73 & 0 & 22 & 13.6 & 45 & 22.2 \\
\hline Winter '74 & 30 & 0 & 18 & 11.1 & 29 & 13.8 \\
\hline Spring '74 & 0 & - & 3 & 33.3 & 55 & 27.3 \\
\hline Summer '74 & 36 & 0 & 6 & 16.7 & 51 & 54.9 \\
\hline Fall'74 & 137 & 0 & 52 & 1.9 & 39 & 59.0 \\
\hline Winter' '75 & 0 & - & 0 & - & 44 & 38.6 \\
\hline Spring '75 & 26 & 0 & 13 & 0.0 & 56 & 42.9 \\
\hline Summer '75 & 0 & - & 1 & 100.0 & 55 & 41.8 \\
\hline Fall '75 & 0 & - & 0 & - & 69 & 27.5 \\
\hline Total & 498 & 0 & 195 & 5.6 & 581 & 36.5 \\
\hline
\end{tabular}

* Of the 53 fish collected during the summer of 1973, 49 were from the Chandeleur Islands; data from Mississippi Sound presented elsewhere disregard these unless stated otherwise. 


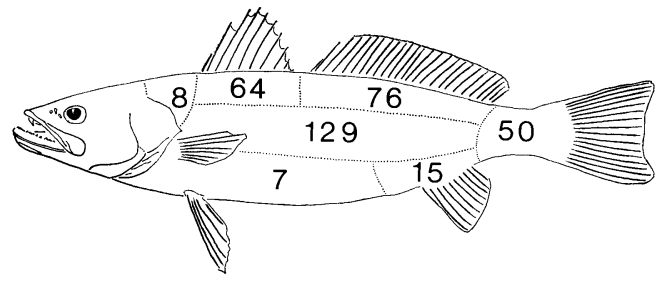

Figure 3. Numbers of Poecilancistrium caryophyllum recovered from different locations within the musculature of spotted seatrout from Mississippi Sound. Three additional larvae occurred in the body cavity.

Fish shorter than $250 \mathrm{~mm}$ each possessed only one worm, whereas longer fish often had more (Fig. 2).

To investigate possible relationships among seasonal fluctuations and variable parameters, I determined correlation coefficients. These coefficients comparing seasonal averages of host length, salinity, maximal salinity, and water temperature both separately and holding each other variable constant against both the seasonal intensity per infected fish and the seasonal number per sampled fish (groups both $>140 \mathrm{~mm}$ and $>250$ ) all failed to disclose significant relationships. Nevertheless, fluctuations tended roughly to correspond nonlinearly with the water's salinity. Seasonal salinity averages measured 23.0 and $25.4 \mathrm{ppt}$ during the summer and fall of 1972 and thereafter ranged
TABLE IV. Frequency distribution of Poecilancistrium caryophyllum in spotted seatrout from Mississippi Sound with Poisson and negative binomial distributions fitted to data.

\begin{tabular}{crrc}
\hline $\begin{array}{c}\text { No. of } \\
\text { larvae } \\
\text { per fish }\end{array}$ & $\begin{array}{c}\text { Observed } \\
\text { no. of } \\
\text { fish }\end{array}$ & $\begin{array}{c}\text { Fitted } \\
\text { Poisson } \\
\text { distribution }\end{array}$ & $\begin{array}{c}\text { Fitted negative } \\
\text { binomial } \\
\text { distribution }\end{array}$ \\
\hline 0 & 1,001 & 920.13 & 999.95 \\
1 & 141 & 261.82 & 147.67 \\
2 & 52 & 37.25 & 46.42 \\
3 & 18 & 3.53 & 17.17 \\
4 & 6 & 0.25 & 6.83 \\
$\geqslant 5$ & 5 & 0.01 & 2.83 \\
$\chi^{2}$ & & $1,997.31$ & 2.78 \\
Level of & & 0.00 & 0.74 \\
\hline
\end{tabular}

between 3.2 and 14.9 ppt except for fall of 1974 when it was $18.2 \mathrm{ppt}$. Those periods of relatively high salinity coincided or overlapped with periods of relatively high incidence of infection.

When Poisson and negative binomial distributions were fitted to the observed frequencies of worms per fish, the negative binomial fitted the data most closely (Table IV).

Infection rates differed in some samples from different geographic areas (Tables V, VI). Exemplifying that difference during fall 1974, more seatrout from Apalachee, Florida, harbored a higher intensity of worms than did those from Texas, Louisiana, and Mississippi (Table V). Fish from Tampa Bay, Florida,

TABLE III. Seasonal intensity of infections with Poecilancistrium caryophyllum in the musculature of spotted seatrout from Mississippi Sound.

\begin{tabular}{|c|c|c|c|c|c|c|c|c|}
\hline \multirow[b]{2}{*}{ Season } & \multicolumn{4}{|c|}{ Fish 140 to $249 \mathrm{~mm} \mathrm{SL}$} & \multicolumn{4}{|c|}{ Fish $>249 \mathrm{~mm} \mathrm{SL}$} \\
\hline & Intensity $\pm \mathrm{SE}$ & $\begin{array}{c}\text { Total } \\
\text { number } \\
\text { of worms }\end{array}$ & $\begin{array}{l}\text { Avg. } \\
\text { length } \\
\text { of worm }\end{array}$ & $\begin{array}{c}\text { Maximal } \\
\text { length } \\
\text { of worm }\end{array}$ & Intensity $\pm \mathrm{SE}$ & $\begin{array}{c}\text { Total } \\
\text { number } \\
\text { of worms }\end{array}$ & $\begin{array}{l}\text { Avg. } \\
\text { length } \\
\text { of worm }\end{array}$ & $\begin{array}{c}\text { Maximal } \\
\text { length } \\
\text { of worm }\end{array}$ \\
\hline Summer '72 & - & - & - & - & $1.7 \pm 0.3$ & 24 & 59.7 & 110 \\
\hline Fall '72 & - & - & - & - & $1.7 \pm 0.3$ & 19 & 50.3 & 115 \\
\hline Winter' '73 & - & - & - & - & $2.6 \pm 0.9$ & 21 & 47.3 & 85 \\
\hline Spring '73 & - & - & - & - & $1.7 \pm 0.3$ & 12 & 66.7 & 100 \\
\hline Summer '73* & $1.0 \pm 0.0$ & 2 & 70.0 & 105 & $1.8 \pm 0.4$ & 16 & 71.1 & 160 \\
\hline Fall '73 & $1.0 \pm 0.0$ & 3 & 59.3 & 65 & $1.1 \pm 0.1$ & 11 & 61.9 & 108 \\
\hline Winter' '74 & $1.0 \pm 0.0$ & 2 & 42.5 & 55 & $1.5 \pm 0.3$ & 6 & 51.3 & 105 \\
\hline Spring '74 & $1.0 \pm 0.0$ & 1 & 48.0 & 48 & $1.3 \pm 0.2$ & 20 & 61.5 & 103 \\
\hline Summer '74 & $1.0 \pm 0.0$ & 1 & 35.0 & 35 & $1.8 \pm 0.3$ & 51 & 69.7 & 143 \\
\hline Fall '74 & $1.0 \pm 0.0$ & 1 & 105.0 & 105 & $2.2 \pm .04$ & 50 & 72.7 & 148 \\
\hline Winter' 75 & - & - & - & - & $1.4 \pm 0.1$ & 24 & 73.1 & 134 \\
\hline Spring '75 & - & - & - & - & $1.8 \pm 0.2$ & 43 & 61.6 & 152 \\
\hline Summer '75 & - & - & - & - & $1.4 \pm 0.2$ & 32 & 87.1 & 136 \\
\hline Fall '75 & - & - & - & - & $1.3 \pm 0.1$ & 25 & 80.6 & 117 \\
\hline Total & $1.0 \pm 0.0$ & 10 & 59.1 & 105 & $1.7 \pm 0.1$ & 354 & 67.6 & 160 \\
\hline
\end{tabular}

* Of the 53 fish collected during the summer of 1973, 49 were from the Chandeleur Islands. 
TABle V. Poecilancistrium caryophyllum in the musculature of spotted seatrout over $250 \mathrm{~mm} \mathrm{SL}$ from Apalachee Bay, Florida; Galveston, Texas; Chandeleur Islands, Louisiana; and Mississippi Sound, during the fall of 1974.

\begin{tabular}{lcccccr}
\hline Locality & $\begin{array}{c}\text { Number } \\
\text { of fish } \\
\text { examined }\end{array}$ & $\begin{array}{c}\text { Percent } \\
\text { of fish } \\
\text { infected }\end{array}$ & $\begin{array}{c}\text { Intensity } \\
\text { per infected } \\
\text { fish }\end{array}$ & $\begin{array}{c}\text { Maximal no. } \\
\text { of worms } \\
\text { per fish }\end{array}$ & $\begin{array}{c}\text { Avg. } \\
\text { length of } \\
\text { worm } \\
\text { (in mm) }\end{array}$ & $\begin{array}{c}\text { Maximal } \\
\text { length } \\
\text { of worm } \\
\text { (in mm) }\end{array}$ \\
\hline Florida & 59 & 98.3 & 4.4 & 16 & 63.4 & 166 \\
Texas & 51 & 45.1 & 1.9 & 11 & 47.9 & 90 \\
Louisiana & 60 & 50.0 & 1.5 & 3 & 69.7 & 145 \\
Mississippi & 39 & 61.5 & 2.2 & 8 & 71.7 & 148 \\
\hline
\end{tabular}

however, revealed lower rates than those from all other listed areas (Table VI). Values for infections from the two separate periods at the same collection sites in Mississippi, Texas, and Louisiana appeared similar.

Sex of host: A $2 \times 2$ chi-square test of homogeneity indicated that infections occur differently between males and females in Mississippi Sound than would be expected by chance alone $\left(\chi^{2}=5.15\right.$ for fish $>249 \mathrm{~mm}$ and 5.76 for fish $>139 \mathrm{~mm}$; both values indicate significance at $2.5 \%$ level). Females outnumbered males 641 to 495 even though a higher percentage of males possessed infections
(310 females vs. 237 males $>249 \mathrm{~mm} ; 104$ and 102, respectively, were infected). Seldom did seasonal samples have an equal number of females and males.

Location of plerocercoid in host: The most common site for the worm in Mississippi seatrout involved the middle of the fillet followed by areas adjacent to the vertebral column below the dorsal fins (Fig. 3). Of three worms from the body cavity, one $30 \mathrm{~mm}$ long individual had about $4 \mathrm{~mm}$ of it penetrating into tissue adjacent to the pericardial sac of a 165 $\mathrm{mm}$ long fish. The most common sites in fish from Mississippi and Texas corresponded dur-

\section{TEXAS}

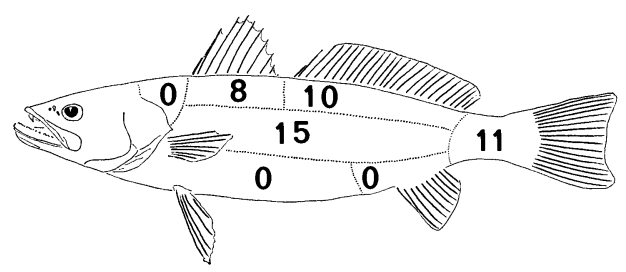

MISSISSIPPI

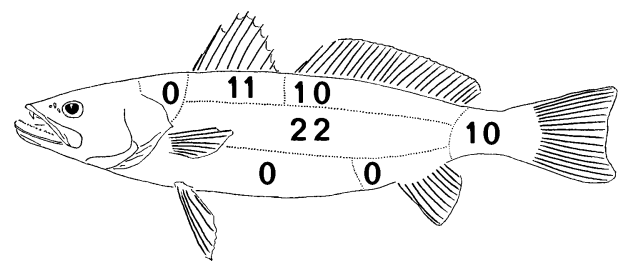

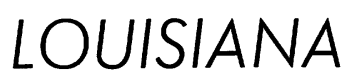

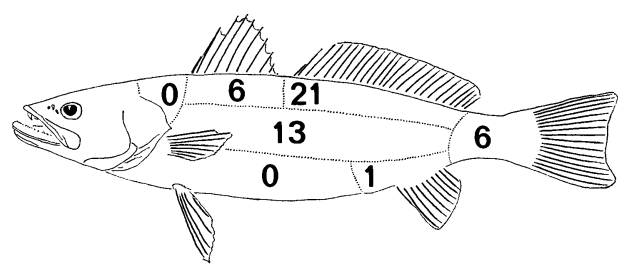

FLORIDA

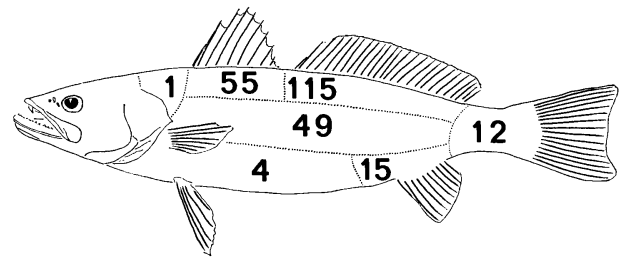

Figure 4. Numbers of Poecilancistrium caryophyllum recovered from different locations within the musculature of spotted seatrout from different areas during the fall of 1974. Two additional larvae occurred in the body cavity of fish from Florida. 
TABLE VI. Miscellaneous values for prevalence and intensity of Poecilancistrium caryophyllum in spotted seatrout during 1976.

\begin{tabular}{|c|c|c|c|c|c|c|}
\hline Location & & Date & $\begin{array}{c}\text { No. fish } \\
\text { examined }\end{array}$ & $\begin{array}{l}\text { Prevalence } \\
\text { in percent }\end{array}$ & Intensity & $\begin{array}{l}\text { Fish length } \\
\text { in } \mathrm{mm} \mathrm{SL}\end{array}$ \\
\hline Mississippi Sound, Mississippi & & Spring 1976 & 26 & 7.7 & 1.5 & 269-372 \\
\hline Mississippi Sound, Mississippi & & Summer 1976 & 11 & 45.5 & 3.4 & $255-440$ \\
\hline Mississippi Sound, Mississippi & & Fall 1976 & 16 & 12.5 & 1.0 & $250-472$ \\
\hline Tampa Bay, Florida & 10 & August 1976 & 18 & 11.1 & 1.0 & $245-307$ \\
\hline Tampa Bay, Florida & 30 & October 1976 & 20 & 10.0 & 1.5 & 246-279 \\
\hline Galveston Bay, Texas & 8 & September 1976 & 15 & 73.3 & 2.4 & 242-578 \\
\hline Galveston Bay, Texas & 14 & November 1976 & 20 & 55.0 & 1.6 & 266-316 \\
\hline Chandeleur, Louisiana & 2 & November 1976 & 23 & 43.5 & 2.7 & $248-356$ \\
\hline
\end{tabular}

ing fall 1974, except that ventral and anterior sites were not involved in fish from Texas (Fig. 4). In Florida, rather than being lateral in the middle of the body, worms prevailed under the second and first dorsal fins, respectively, and in Louisiana they predominated under the second dorsal fin.

To examine for internal migratory routes, data were analyzed according to host lengthgroups: $<250,250$ to 269,270 to 299 , and $>299 \mathrm{~mm}$. The small number of infected young fish hindered critical evaluation, but in that group, most worms occurred anteriorly; no worms occurred in the caudal area or adjacent to the second dorsal or anal fins. No seasonal differences in sites nor obvious indications of migration other than a possible shift from anterior to more posterior locations were apparent.

Effect on host: Sampled fish less than 140 $\mathrm{mm}$ did not possess infections. To test whether plerocercoids altered growth in adult hosts, I computed condition coefficients, or $\mathrm{K}$ values, for each individual fish (Petrushevsky and Kogteva, 1954). Since infections reached highest levels in fish from Florida, values for those fish demanded especial attention. I compared $\mathrm{K}$ values based on the entire weight of hosts having more than five worms with those having two or fewer worms, keeping males and females separate. In both sexes, the averages ( 1.33 vs. 1.44 for males, 1.39 vs. 1.45 for females) differed-but not significantly-when a Mann Whitney test was used to compare values. Little difference was noted among average $\mathrm{K}$ values of fish from Florida, Mississippi, and Louisiana. Fish from Texas had been eviscerated and were not comparable. Considerable variation, however, existed among $\mathrm{K}$ values for individuals of the same sex col- lected the same season, even in Mississippi with the relatively large sample; thus, any effect caused by a small number of worms was not apparent, even when gonad weight was subtracted from entire weight.

No apparent difference existed between weights or relative weights of livers from infected and noninfected fish.

\section{DISCUSSION}

Even though Poecilancistrium caryophyllum constitutes the most prevalent sciaenid trypanorhynch studied, its life cycle has not been completely established. The plerocercoid develops to maturity when a carcharhinid shark eats an infected sciaenid. In Mississippi Sound, the bull shark, Carcharhinus leucas (Valenciennes), especially individuals over $135 \mathrm{~cm}$ long, probably acts as the primary host. Several distal proglottids of this tapeworm develop eggs while still attached. When detached segments come in contact with sea water, they split along the ventral surface, releasing numerous eggs. The pyriform eggs, about $32 \mu \mathrm{m}$ long and lacking any adhesive qualities sink, presumably to the substratum. These eggs, unlike those of most trypanorhynchs studied, but assumed by Parker (1951) and others in popular treatments, have an operculum and contain a coracidium. A copepod or other small adult crustacean could act as the first intermediate host, but these crustaceans are not important dietary components of sea trout longer than $14 \mathrm{~cm}$. Whether a larger crustacean host serves as a first or second intermediate host and whether a crustacean or fish acts as a paratenic host will be studied by Tom Mattis. Based on the two assumed life cycle types (Mudry and Dailey, 1971), one expects a single crustacean host available to the sciaenid. 
When the fish eats the intermediate host, the larva develops into the plerocercoid within the musculature. Goldstein (1963) considered $P$. robustum (Chandler 1935a), originally described from the spotted seatrout in Texas, and two other species as synonyms of $P$. caryophyllum; I follow that treatment here.

Less is known about the biology of the other encountered cestodes, and the taxonomic status of some needs further attention. The plerocercoid reported by Schlicht and McFarland (1967) as Diplootobothrium springeri Chandler 1942 from the black drum in Texas probably is what I call Pseudogrillotia pleistacantha. Tom Mattis has an adult D. springeri sensu stricto from Sphyrna lewini (Griffith and Smith) off Pensacola, Florida, and, based on available material, its hooks differ from those of $P$. pleistacantha in the drum. The hooks of my specimens of $P$. pleistacantha, however, form a more regular pattern than those described by Dollfus (1969). Pterobothrium lintoni is a senior synonym of $P$. malleus (Linton 1924) and is probably the large yellowish plerocercoid from Menticirrhus americanus (Linnaeus) in Texas identified as Pterobothrium sp. by Schlicht and McFarland (1967). Adult worms have been collected from the stingrays Dasyatis sayi (Lesueur) and D. americana Hildebrand and Schroeder in Mississippi by Tom Mattis. Until a review of $P$. heteracanthum can clarify that European material differs specifically from that in the Gulf of Mexico and Western Atlantic, I follow Dollfus (1942) in considering my specimens from the Atlantic croaker as $P$. heteracanthum. Chandler (1935b) reported it from croaker in Texas as Gymnorhynchus gigas (Cuvier 1817), which he later (1942) considered $P$. filicolle (Linton 1889).

Ecological studies with some aspects in common with mine have been conducted on Poecilancistrium caryophyllum from a variety of fishes in the summer of 1958 in the Texas coastal region extending between San Antonio Bay and the southern end of the Upper Laguna Madre (Schlicht and McFarland, 1967) and yearly between 1973 and 1975 from the spotted seatrout in Louisiana (Boertje, 1976). The prevalence in the different fishes in Mississippi approximates that reported by Schlicht and $\mathrm{McF}$ arland. Showing the greatest difference between the two areas, the prevalence in silver perch from Texas was $45 \%$ of fish in the infected length-range compared to $16 \%$ from Mississippi. The dissimilarity can probably be accounted for by differences in specific habitats and by the perch's ability to migrate. My value for prevalence in croaker is deceptively high because numerous additional croaker not included in the table had few infections. Based on numerous unlisted black drum examined for Pseudogrillotia pleistacantha, P. caryophyllum can be estimated to infect about $5 \%$ of those fish, sometimes together with the other cestode.

In spite of the fact that Schlicht and McFarland examined spotted seatrout mostly between 16 and $26 \mathrm{~cm}$ long, lengths fitting into a trough between length-modes observed in Mississippi, both prevalence and intensity of infections of $P$. caryophyllum are similar in the two regions. Prevalence for fish within the infected length-groups, 30 and $34 \%$, differs from the $49 \%$ indicated in Louisiana (Boertje, 1976). However, when comparing values from Texas, Louisiana, and Mississippi in Tables V and VI, one realizes that both prevalence and intensity fluctuate some, but remain similar. Values for infections in fish from Tampa Bay and Apalachee Bay, Florida, however, differ from each other and from those in other states.

The difference in infections of Florida fish can be explained by the habitats (McNulty et al., 1972). In Apalachee Bay where prevalence and intensity values were almost double those in other areas, the salinity was usually greater than $30 \mathrm{ppt}$ near shore with some seagrasses present. Many shark and intermediate hosts probably inhabit the region. Even though the salinity reached above 25 ppt in Tampa Bay, conditions resulting from pollution and hydrographic features provide a less favorable environment for necessary hosts. Proper intermediate and shark hosts must occur, and migrations of either of these hosts into or out of the fishing grounds influence fluctuations in infections.

Salinity, probably by regulating the number of intermediate hosts, at least partially influences transmission of $P$. caryophyllum to the seatrout. Previously, Parker (1951) made some indication and Guest and Gunter (1958) were more positive about an increase in the number of inquiries about infections by the same worm and a presumed increase in its prevalence 
during the early 1950's; they suggested that that increase corresponded to high salinity levels caused by an extended drought. William Demoran of GCRL supplied me with November averages taken from the Laboratory pier between 1952 and 1955 ranging between 24.2 and $27.0 \mathrm{ppt}$.

Fishermen when questioned often adamantly proclaim the presence of more extensive infections during one particular season. These seasons often differ among fishermen, even from the same locality. Such differences should be expected when considering the fluctuations among both seasons and years. Fishermen cited by Chandler (1935a) complained that winter months produced particularly "wormy" fish. Incompletely developed plerocercoids were uncommon during all seasons, suggesting a lack of concentrated seasonal recruitment.

Host length clearly relates directly with prevalence, but not with intensity of the plerocercoid (Fig. 2). The large standard errors, especially for intensity of worms in fish greater than $405 \mathrm{~mm}$, suggests that large fish acquiring their initial infection often contract more worms than smaller fish. This seems credible since they need more food and consequently obtain more intermediate hosts. Data of Boertje (1976) based on 240 fish suggest an increase in both prevalence and intensity with host length, but he does not present standard errors for intensity values.

Two possible explanations exist for the absence of the larva in fish shorter than $140 \mathrm{~mm}$. Either the intermediate host is unavailable to or not preferred by the trout or the worm may infect and kill or weaken the trout so that it becomes vulnerable as prey.

Data presented support a mechanism of hostimmunity to challenge infections in adult fish. As trout grow, a higher percentage of individuals become infected, but not necessarily with more worms. If some large fish continually acquire initial infections as indicated, I would expect the previously infected fish to also be feeding on infected hosts and increasing extensively their loads of plerocercoids such as exemplified by haddock with Grillotia erinaceus (van Beneden 1858) in the North Sea which Lubieniecki (1976) reported. Such an increase does not occur. Consequently, availability of $P$. caryophyllum seems a less likely explanation for the relatively consistent intensity values than one involving resistance such as antibodies produced in response to procercoids or early plerocercoid stages. Relatively heavy infections in seatrout from Apalachee Bay can be explained by initial heavy infections resulting from greater availability of the intermediate host. A resistance to challenge infections is also supported by the tendency towards a negative binomial frequency distribution. Many other factors can produce such a distribution, and Crofton (1971) listed a few. Of these, nonrandom distribution of infective intermediate hosts and variability related to host length and salinity probably influence the distribution some. Data from a large sample collected at one time might have produced an even closer fit.

Immune rejection mechanisms against cestodes apparently occur in fishes, but have not been well documented. MacKenzie (1975) obtained single precipitin bands in Ouchterlony plates formed between plerocercoids of Gilquinia squali Fabricius 1794 and sera of 5+ and 6+ year-old infected whiting [Merlangius merlangus (Linnaeus)]. Sera of younger infected fish did not produce a reaction nor did material from dace [Leuciscus leuciscus (Linnaeus)] infected by Caryophyllaeus laticeps (Pallas 1781) tested by Kennedy and Walker (1969), even though that fish rejected challenge infections of the cestode. Schistocephalus solidus (Mueller 1776), in a fashion consistent with antibody-formation, became rejected from a secondary, but not primary, piscine intermediate host (Orr et al., 1969). No evidence indicated that the seatrout is not a primary piscine host for $P$. caryophyllum.

Even though the results show a difference in male and female hosts, I question the importance of this finding. Members of the same sex often school together and consequently one group will occasionally receive heavier infections because it occurs near concentrations of the intermediate host. Differences cannot be used as indicators of migration of the fish in Mississippi, and analyses threequarters through the study and from fish from other states failed to detect statistically discernible differences. Boertje (1976) doubted any relationship between infections and host sex. 
Over $80 \%$ of the larvae should be clearly obvious to someone filleting seatrout. Many people who eat or sell infected fish evince great disgust, but many others remain justifiably unconcerned or unaware of infections. Some consumers bake the fish whole rather than filleting it, whereas others believe exposed worms are fascia, nerves, or some other anatomical feature of the fish.

These larvae may kill or harm young fish. On the basis of three fish 142 to $165 \mathrm{~mm}$ long, each with a single incompletely developed plerocercoid either pressed against the pericardial sac or otherwise occupying a potentially harmful site in the anterior portion of the host, some fish probably die from infections. If trout less than $140 \mathrm{~mm}$ readily feed on intermediate hosts, then large numbers probably die or become vulnerable to predators.

On the other hand, worms do not appear to harm adult fish. The $\mathrm{K}$ values do not indicate any relationship between fish growth and infections. Usually when cestode larvae affect growth, the parasite is relatively large (e.g., Pollard, 1974) or the host is young (e.g., Smith, 1973). Even though cestodes have been known to influence liver weight (e.g., Arme and Owen, 1967), no indication was evident that trout livers became altered. Poecilancistrium caryophyllum may have a detrimental effect on oxygen consumption (e.g., Lester, 1971) or other processes, but such an effect was not evident or studied.

Schlicht and McFarland (1967) suggested a differential mortality of parasitized versus nonparasitized fish because those authors found an absence of infections in spotted seatrout over $400 \mathrm{~mm}$ long. They looked at only five fish in that range. In the present Texas (Galveston) samples, 8 of 11 fish in that range had infections which averaged 2.1 worms each. From Mississippi Sound, 26 of 46 fish over $400 \mathrm{~mm}$ harbored infections, and the rate appears to increase with host length. Boertje (1976) presented similar results. Thus, I find no evidence for selected mortality of large infected fish.

Seatrout seem to tolerate the plerocercoid for long periods. One $525 \mathrm{~mm}$ long fish from Texas possessed what appeared to be two degenerate worms possibly present as long as 6 to 7 years based on the assumption that the fish approximated 8 years of age (Pearson, 1929) and acquired the infection when young. These two worms had been encapsulated by a thin connective tissue layer and incorporated some melanin. Three worms from two trout 295 and $280 \mathrm{~mm}$ long from Apalachee Bay, Florida, had acquired a yellowish coloration and a more firm consistency than typical $P$. caryophyllum. None had evident host-capsules, but one had a few fluid-filled vesicles along the extension of the blastocyst. These latter worms, probably 1 to 2 years of age, may have undergone initial stages of degeneration. Most fish estimated as 3 and 4 years old possessed healthy-appearing worms, suggesting the age of worms as 1 to 3 years. The fish with the degenerate worms also had three living ones, suggesting the possibility of premunition.

\section{ACKNOWLEDGMENTS}

Ronnie G. Palmer examined most of the fish and Thomas Deardorff and Alan Fusco obtained most of the 1976 raw data. Tom Mattis identified and provided useful information on some cestodes; Paul Poole, David Boyes, and Lois Coquet performed computer services; Kenny Melvin provided most of the small seatrout; and Ned Whatley, Ann St. Andrie, and Roswitha Buxton provided additional technical assistance.

\section{LITERATURE CITED}

ARME, C., AND R. W. OwEN. 1967. Infections of the three-spined stickleback, Gasterosteus aculeatus L., with the plerocercoid larvae of Schistocephalus solidus (Müller, 1776), with special reference to pathological effects. J Parasitol 57: 301-314.

Boert JE, S. B. 1976. Incidence and significance of plerocercoid infections of Cynoscion nebulosus in relationship to Felis domestica L. Proc La Acad Sci 39: 23-27.

Chandler, A. C. 1935a. A new tetrarhynchid larva from Galveston Bay. J Parasitol 21: 1-2.

Bay. Proc U S Nat Mus 83: 123-157.

1942. Some cestodes from Florida sharks. Proc U S Nat Mus 92: 25-31.

Crofton, H. D. 1971. A quantitative approach to parasitism. Parasitology 62: 179-193.

Dollfus, R. Ph. 1942. Etudes critiques sur les tétrarhynques du muséum de Paris. Arch Mus Natl Hist Nat Paris. s.6 19: 7-466.

1969. Quelques espèces de cestodes Tétrarhynques de la côte Atlantique des Etats 
Unis, dont l'une n'était pas connue à l'état adulte. J Fish Res Board Can 26: 10371061.

Goldstein, R. J. 1963. A note on the genus Poecilancistrium Dollfus, 1929 (Cestoda: Trypanorhyncha). J Parasitol 49: 301-304.

Guest, W. C., AND G. Gunter. 1958. The sea trout of weakfishes (genus Cynoscion) of the Gulf of Mexico. Gulf States Mar Fish Comm Tech Sum No. 1: $1-40$.

Kennedy, C. R., AND P. J. Walker. 1969. Evidence for an immune response by dace, Leuciscus leuciscus, to infections by the cestode Caryophyllaeus laticeps. J Parasitol 55: 579-582.

LEster, R. J. G. 1971. The influence of Schistocephalus plerocercoids on the respiration of Gasterosteus and a possible resulting effect on the behavior of the fish. Can J Zool 49: $361-366$.

LUBIENIECKI, B. 1976. Aspects of the biology of the plerocercoid of Grillotia erinaceus (van Beneden, 1858) (Cestoda: Trypanorhyncha) in haddock Melanogrammus aeglefinus (L.). J Fish Biol 8 : 431-439.

MacKenzie, K. 1975. Some aspects of the biology of the plerocercoid of Gilquinia squali Fabricius 1794 (Cestoda: Trypanorhyncha). J Fish Biol 7: 321-327.

McNulty, J. K., W. N. Lindall, JR., AND J. E. Syles. 1972. Cooperative Gulf of Mexico estuarine inventory and study, Florida: Phase I, area description. NOAA Tech Rep NMFS CIRC-368. $126 \mathrm{p}$.
Mudry, D. W., and M. D. DaIley. 1971. Postembryonic development of certain tetraphyllidean and trypanorhynchan cestodes with a possible alternative life cycle for the order Trypanorhyncha. Can J Zool 49: 1249-1253.

Orr, T. S. C., C. A. Hopkins, and G. H. Chardes. 1969. Host specificity and rejection of Schistocephalus solidus. Parasitology 59: 683-690.

ParkeR, R. H. 1951. Why these wormy trout? Tex Game Fish June: 2-3.

Pearson, J. C. 1929. Natural history and conservation of redfish and other commercial sciaenids on the Texas coast. Bull Bur Fish 44: 129-214.

Petrushevsky, G. K., and E. P. Kogteva. 1954. [Effect of parasitic diseases on the condition of fish.] Zool Zh 33: 395-405. Trans. by L. Margolis, Fish Res Board Can Trans Ser No. 1405.

Pollard, D. A. 1974. The biology of a landlocked form of the normally catadromous salmoniform fish Galaxias maculatus (Jenyns) VI. Effects of cestode and nematode parasites. Aust J Mar Freshwater Res 25: 105120.

SchLICHT, F. G., AND W. N. McFarLand. 1967. Incidence of trypanorhynchan plerocercoids in some Texas coast sciaenid fishes. Contrib Mar Sci 12 : 101-112.

SмrтH, H. D. 1973. Observations on the cestode Eubothrium salvelini in juvenile sockeye salmon (Oncorhynchus nerka) at Babine Lake, British Columbia. J Fish Res Board Can 30: 947-964. 